\title{
Satellite Application for Felt Earthquake Events in Sabah, Malaysia
}

\author{
A. Sali, D. Zainal, N. H. Tauhid Ahmad, and M. F. Omar
}

\begin{abstract}
The recent earthquake in Ranau, Sabah on 5 June 2015, which killed 18 people,has opened up the reality of impending earthquakes in Malaysia since the country had never experience any major earthquake before. To monitor the earthquake events, the Malaysian Meteorological Department (MetMalaysia) has the system implemented a real-time and remote earthquake monitoring all over Malaysia since 2004. The system helps in extracting the data for development of a possible Earthquake Warning System (EWS). From data obtained from the system, this paper analyses relation between felt earthquake events and seismic parameters such as intensity, distance to epicentre, foundation and elevation of seismic stations. The events under study occurred in Sabah, Malaysia, from 2004 to 2014. In particular, displacement (D), accelerated velocity (V) and acceleration (A) from 2004 to 2014 are analysed and discussed. The feasibility of modelling two outstanding felt earthquake events is assessed using Gaussian distribution with reasonable RMSE values.
\end{abstract}

Index Terms - Earthquake warning system, Sabah, Malaysia.

\section{INTRODUCTION}

Earthquake occurrence is one of the significant events in nature that causes both irretrievable financial and physical harm. Apparently the monitoring of earthquake is essential in developing Early Warning System (EWS) for disaster management is proposed. The geological and seismotectonic information of the South East Asia region showed that Malaysia do face certain degree of threats from major earthquakes originating from the surrounding regions as well as from local earth tremors [1]. These potential threats are in the form of tsunami and ground shaking. In [2], the earthquake epicenter data of past 80 years of the Southeast and East Asian region is shown.

From [2], several epicenters are shown in the Straits of Malacca, however the magnitude is small, less than $4 \mathrm{Mb}$. The intermediate depth earthquakes of adjacent to Sumatera with magnitudes in excess of 6 could possibly produce moderate ground shaking in Peninsular Malaysia may be hazardous to high-rise buildings [2]. For East Malaysia region, two earthquakes in the Sulawesi area with magnitude more than 7 caused ground shaking in Sabah, specifically at Tawau and Kota Kinabalu [2]. From [1], seismotectonic map of active fault is scattered in area of Sabah. Data from Minerals and Geoscience Department (JMG) reported Ranau region of

Manuscript received April 30, 2016; revised August 21, 2016

A. Sali is with Universiti Putra Malaysia (UPM), Malaysia (e-mail: aduwati@upm.edu.my).

D. Zainal, N. H. Tauhid, and M. F. Omar are with National Space Agency, Malaysia (ANGKASA), Malaysia (e-mail: dasimah@angkasa.gov.my, noorhidayah@angkasa.gov.my, farid@angkasa.gov.my). central Sabah, has strong topographic relief and even moderate magnitude earthquakes are likely to induce large-scale mass movements (landslides) [2].

This paper proposes an analysis on seismic data and seismic station parameters in Sabah, Malaysia. By using Gaussion distribution to model displacement, velocity and acceleration, the least RMSE is used to correlate with the earthquake event parameters. Part II explains felt earthquake events in Sabah, and the earthquake monitoring system in use. Part III presents the analysis of these earthquake events, emphasising on intensity, distance, foundation and elevation of the station. The paper is finally concluded in Part IV.

\section{EARTHQUAKES IN SABAH, MALAYSIA}

\section{A. Seismology Stations}

Malaysia Meteorological Department, known as MetMalaysia, has developed seismic station network with the objective to monitor earthquake activity since 1976. Currently, 20 seismic stations has been operated all across Peninsular and East Malaysia comprising of 8 weak motion stations and the remaining 12 are strong motion stations. For remote stations, seismic wave data received at each stations are being recorded in real time which is then transmitted using VSAT satellite communication system to MetMalaysia Head Quarters data centre [3]-[5].

\section{B. Remote Earthquake Monitoring System}

Geostationary satellite system is being utilised for the seismic data transmission from the station to the head quarter data centre due to seismic limited access and unavailability of terrestrial communication infrastructure at every remote location seismic station. Very Small Aperture Terminal (VSAT) robust system will provide continuous communication solution for the early warning system that requires very high availability even during exceptional circumstances [6]. The solar panels will power the batteries and indoor communications unit (IDU) of VSAT system for the real-time seismic data transmission from station to the satellite network operation centre. The setup and configuration for a remote earthquake monitoring using geostationary satellite network is shown in Fig. 1.

The seismic station will be put in a quite area to minimize ground vibrations and other type of noise, which would degrade the seismic signal. The seismic equipment, data acquisition system, indoor communication unit (IDU) is housed inside a small building. A fence will be erected at the entire site around the station. Seismometer and accelerometer is the key instrument at the station. It detects and measures earth ground motion. Both instruments will be placed on a 
concrete pad which directly contact with the bedrock. The signals are converted to digital records and stored in a data storage unit. The seismometer is extremely sensitive and can pick up a broad spectrum of motions.

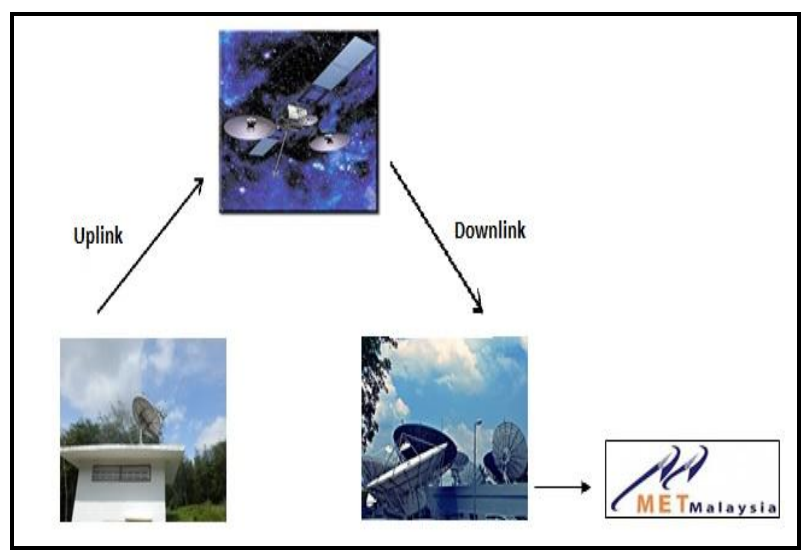

Fig. 1. Satellite signal transmission configuration for a remote seismic station.

Three directions of motions can be measured by the seismometer and accelerometer consist of North-South, East-West and Up-and-Down (Vertical). It provides seismic data - Displacement (D), Accelerated velocity (V) and Acceleration (A). The field station components are shown in Fig. 2.

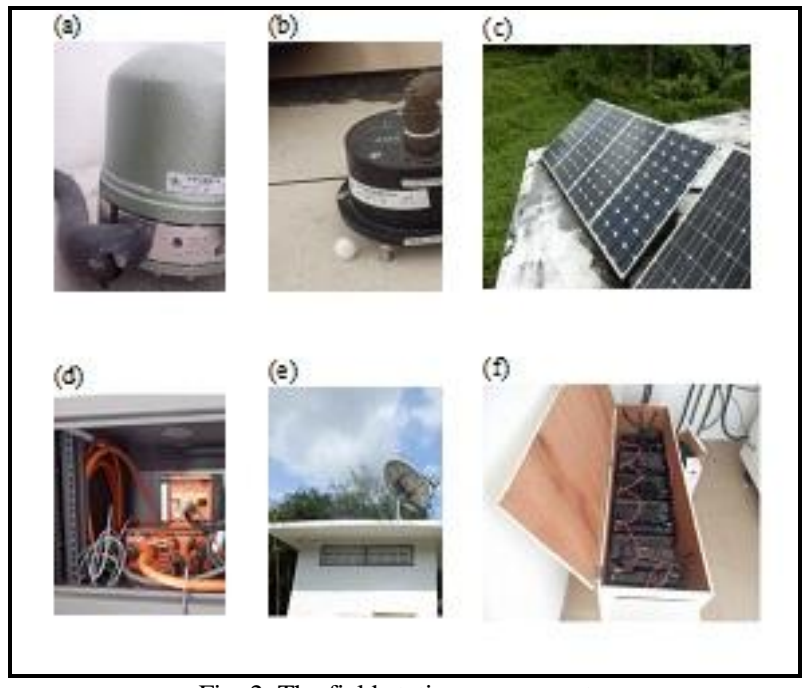

Fig. 2. The field station components.

TABLE I: SATELLITE TRANSMISSION PARAMETERS

\begin{tabular}{|l|l|l|}
\hline \multicolumn{1}{|c|}{ Parameter } & Variable & Value \\
\hline $\begin{array}{l}\text { Operating } \\
\text { frequency }\end{array}$ & $f$ & $\begin{array}{c}6 \mathrm{GHz} \text { (uplink) } / \\
4 \mathrm{GHz} \text { (downlink) }\end{array}$ \\
\hline Satellite & $S$ & Measat3a \\
\hline Satellite position & $S_{y}$ & $91.5^{\circ} \mathrm{E}$ \\
\hline EIRP & $P_{R x}$ & $57 \mathrm{dBW}$ \\
\hline Antenna diameter & $d_{a n t}$ & $1.8 \mathrm{~m}$ \\
\hline
\end{tabular}

The real-time transmission of seismic data is relayed from remote seismology stations back to the control and processing centre over the satellite network. The parameters in the satellite transmission are presented in Table I. The backhaul network configuration for the satellite transmission is shown in Fig. 3. Block diagram for the setup and configuration of the seismic sensors and the communication unit is presented in Fig. 4.

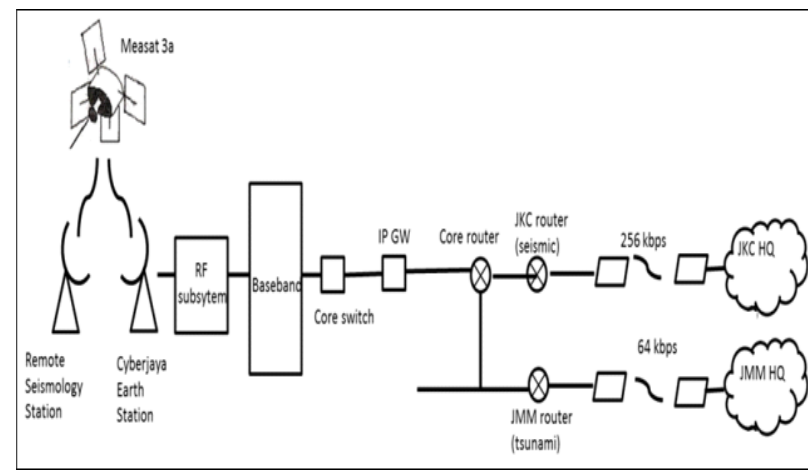

Fig. 3. Backhaul network configuration for satellite transmission.

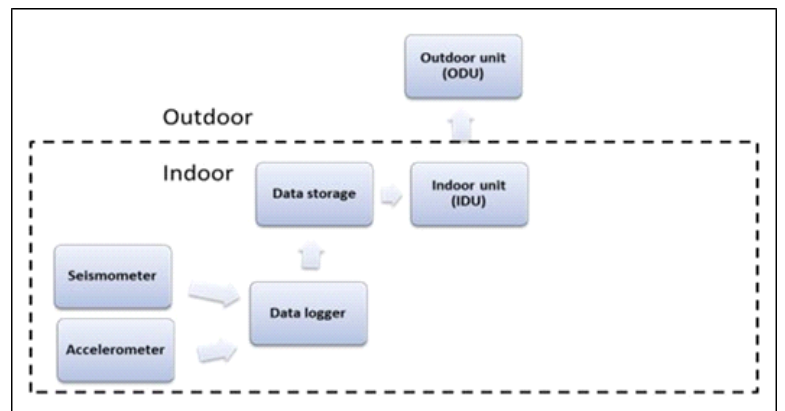

Fig. 4. Block diagram for the setup and configuration of the seismic sensors and the communication unit.

\section{ANALYSIS OF FELT EARTHQUAKE EVENTS IN SABAH}

\section{A. Felt Earthquake Event}

In this paper, Sabah had been chosen as the area of study since felt earthquake recorded by the Malaysia Metrological Department (MMD) seismic system are significant which showed 28 earthquake felt event occurrence across the state of Sabah for the past 10 years.Gaussian distribution was used to model the events. From this model, RMSE is calculated. The lowest RMSE recorded for a particular event is used to indicate a level of accuracy in the model. A lower RMSE reflects a better model and vice versa. The RMSE values for respective events are shown in Tables $\mathrm{A}, \mathrm{B}$ and $\mathrm{C}$ in the Appendix.

\section{B. Intensity}

The effect of an earthquake on the Earth's surface is called the intensity [7]. The Modified Mercalli Intensity Scale is one of intensity scales have been developed to evaluate the effects of earthquakes. Modified Mercalli (MM) Intensity Scale was developed in 1931 by the American seismologists Harry Wood and Frank Neumann in United States. This scale, composed of increasing levels of intensity that range from imperceptible shaking to catastrophic destruction and designated by Roman numerals. Fig. 5 [2], [8] shows zones of ground shaking intensity in Malaysia in terms of the Modified Mercalli Intensity scale according to the Malaysian Meteorological Department. The MMI VII of very strong ground shaking in Sabah was produced by earthquakes with epicentres located within the state. Fig.6 illustrates the relationship between RMSE and MM Intensity by intensity level. It is found and observed that the values of RMSE are 
highly correlated to the intensity level. The higher intensity more lower the RMSE.

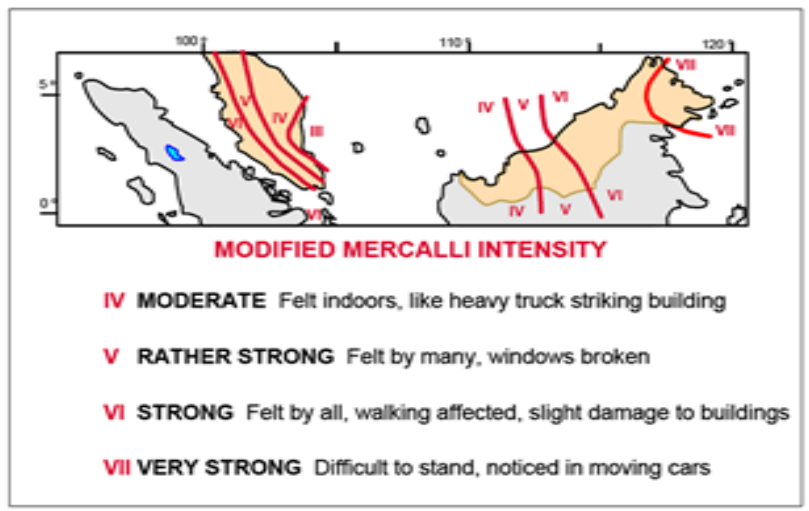

Fig. 5. Ground Shaking Intensity in Malaysia as per MMI scale [1].

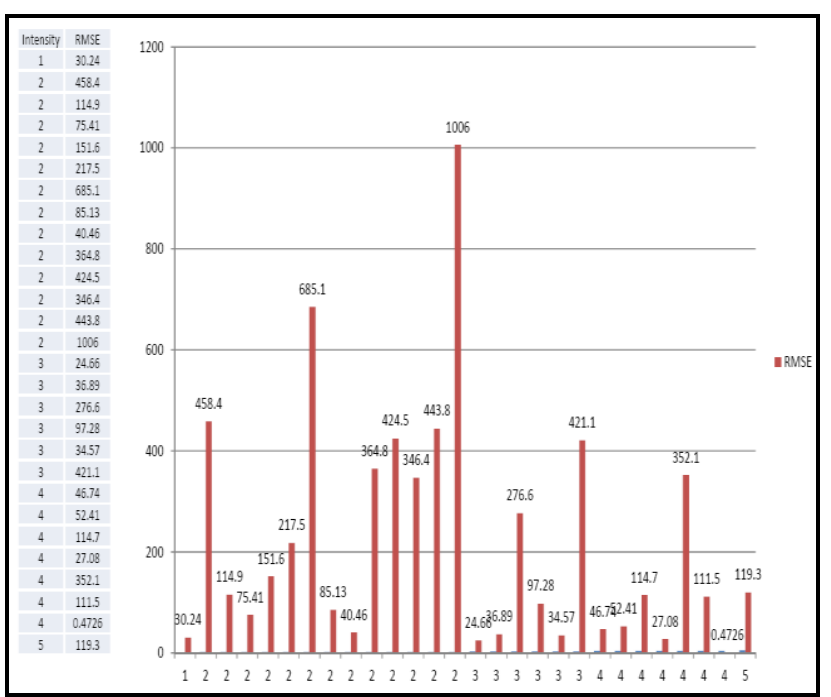

Fig. 6. Relationship between RMSE and MM Intensity by intensity level.

\section{Distance}

According to the three seismic parameters analyse, as per smallest RMSE value for Acceleration (A), Velocity (V) and Displacement (D), it is found and observed that lower values of Distance, Velocity and Acceleration are highly correlated to smaller value in distance-to-epicentre. In Fig. 7 the Gaussian distributions for the seismic Distance (D) parameters has resulted RMSE value 6.004, the distance to the epicentre is $868.696 \mathrm{~km}$. With RMSE value at 19.22 for the Velocity (V) parameter, the distance is $1037.099 \mathrm{~km}$ as in Fig.8 and with RMSE value at 0.4726 , the distance in 336.375 $\mathrm{km}$ to the epicentre as is shown in Fig. 9. It can be observed from the analysis, the lowest RMSE for acceleration, velocity and distance parameter has recorded the lowest distance value in kilometre from the epicentre of the earthquake event.

\section{Foundation}

The seismology stations in Malaysia had been built in a quite area to minimize ground vibrations and other type of noise, which would degrade the seismic signal. In Sabah, most of the foundation for seismology stations are sandstone as shown in the Table II as below:

The data from 2004 - 2014 had been study to understand the correlation between seismology foundation and lowest RMSE value in Gaussian distribution. Lowest RMSE value for each seismology station foundation was analysed and
Table III shows $79.3 \%$ of earthquake events in Sabah had impacted sandstone foundation station.

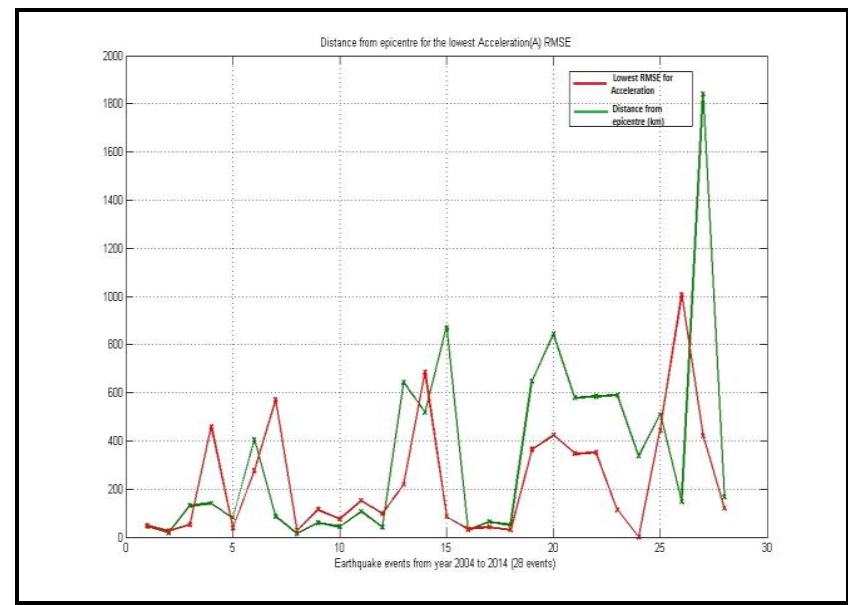

Fig. 7. Parameter for distance (in $\mathrm{km}$ ) to the lowest RMSE acceleration.

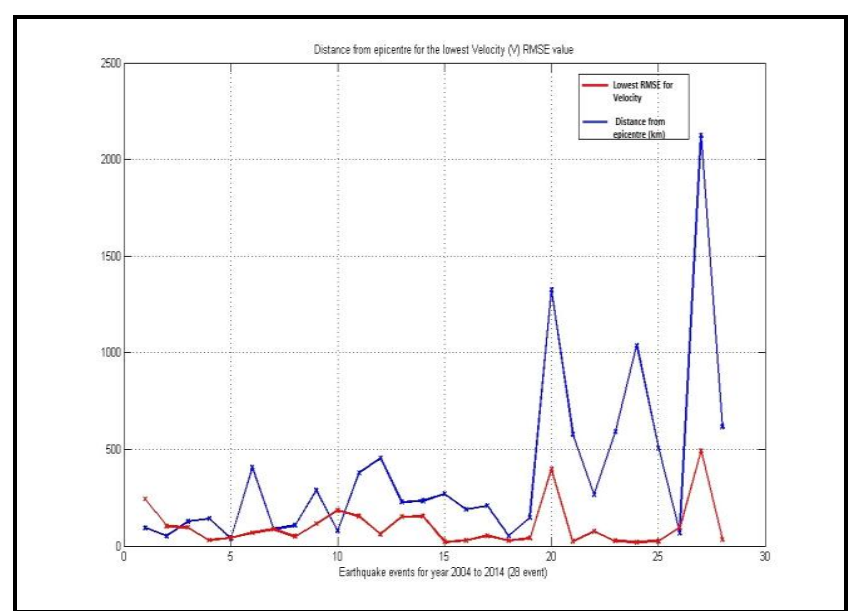

Fig. 8. Parameter for distance (in km) to the lowest RMSE velocity.

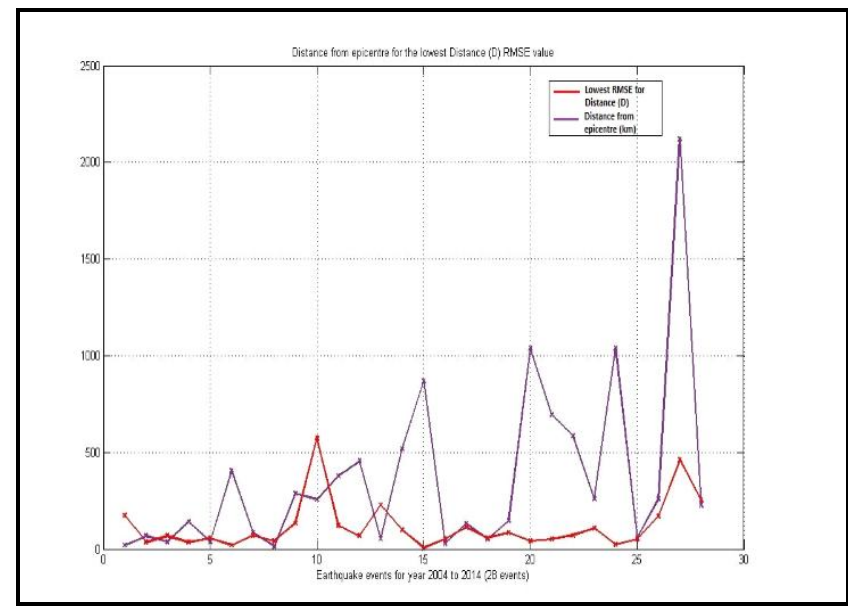

Fig. 9. Parameter for distance (in $\mathrm{km}$ ) to the lowest RMSE displacement.

The relation between $\mathrm{D}, \mathrm{V}$ and A parameters and lowest RMSE value for each impacted station foundation shown in the Fig. 10, Fig.11 and Fig.12. From the analysis, significant trend between lower RMSE value and sandstone station could indicated stronger felt earthquake event.

\section{E. Elevation}

Elevation of the seismology stations is one of the information recorded in the seismic data analysis for earthquake monitoring in Sabah. Table IV shows the seismology stations, their respective identification (id) and 
the foundations of the stations.

TABLE II: FOUNDATION OF SEISMOLOGY STATION IMPACTED BY EARTHQUAKE IN SABAH

\begin{tabular}{|c|c|c|c|}
\hline \multicolumn{3}{|c|}{ Seismology Station } & \multirow[t]{2}{*}{ Foundation } \\
\hline $\begin{array}{l}\text { Station } \\
\text { Name }\end{array}$ & Latitude & Longitude & \\
\hline $\begin{array}{c}\text { KDM } \\
\text { (Kudat) }\end{array}$ & 6.91670 & 116.83330 & Granite \\
\hline $\begin{array}{c}\text { KKM } \\
\text { (Kota } \\
\text { Kinabalu) }\end{array}$ & 6.04430 & 116.21470 & Sandstone \\
\hline $\begin{array}{c}\text { RNSM } \\
\text { (Ranau) }\end{array}$ & 5.95481 & 116.68159 & Rocky \\
\hline $\begin{array}{c}\text { SDM } \\
\text { (Sandakan) }\end{array}$ & 5.64090 & 117.19500 & Sandstone \\
\hline $\begin{array}{c}\text { SPM } \\
\text { (Sapulut) }\end{array}$ & 4.70830 & 116.46500 & Sandstone \\
\hline $\begin{array}{r}\text { BTM } \\
\text { (Bintulu) } \\
\end{array}$ & 3.20000 & 113.08330 & Sandstone \\
\hline $\begin{array}{c}\text { LDM } \\
\text { (LahadDatu) }\end{array}$ & 5.17770 & 118.49800 & Sandstone \\
\hline $\begin{array}{r}\text { TSM } \\
(\text { Tawau }) \\
\end{array}$ & 4.29360 & 117.87250 & Granite \\
\hline $\begin{array}{r}\text { BNM } \\
\text { (Bakun) }\end{array}$ & 2.77670 & 114.03500 & Sandstone \\
\hline $\begin{array}{c}\text { SBM } \\
(\mathrm{Sibu})\end{array}$ & 2.45290 & 112.21400 & Sandstone \\
\hline
\end{tabular}

TABLE III: LOWEST RMSE AT SEISMOLOGY STATION FOUNDATION

\begin{tabular}{|l|c|}
\hline Foundation & Occurrence of earthquake \\
\hline Sandstone & 23 \\
\hline Rocky & 1 \\
\hline Granite & 4 \\
\hline
\end{tabular}

From these stations, a record of seismic data is analysed. Gaussian distribution model is used and the station which recorded the lowest root mean square error (RMSE) is considered as an event [9]. From this list of stations with the lowest RMSE for each felt earthquake event, a histogram is plotted to observe which stations shows the lowest RMSE, as in Fig. 13.

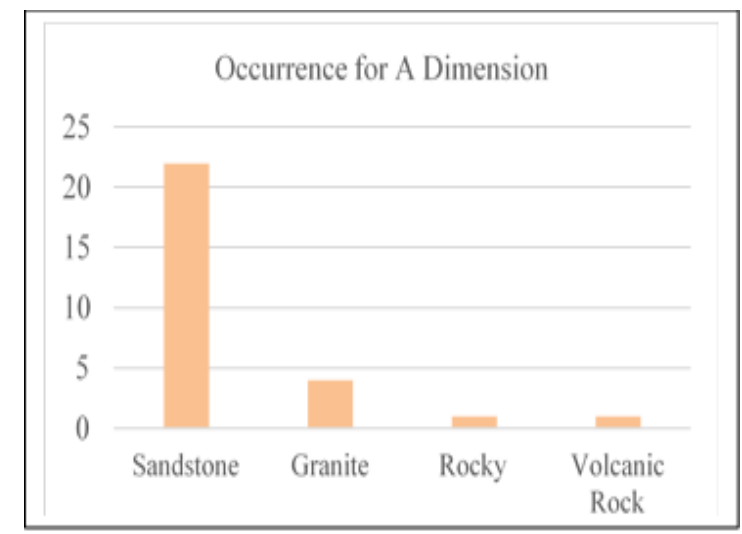

Fig. 10. Occurrence of earthquake events at lowest RMSE value for A dimension.

In Fig. 13, the histogram of felt earthquake events in Sabah is shown, as a function of elevation (in metre) of the seismology stations. It can be seen that Kota Kinabalu station (marked as seismology station id 'KKM'), which $813 \mathrm{~m}$ in elevation, recorded the highest number of earthquake events. It is also noted that the foundation of this station is sandstone, similar to most other stations (refer Table IV). From this observation, it is noticed that Kota Kinabalu stations observe the lowest RMSE from the Gaussian model. For example, although an earthquake happened in Ranau, but Ranau seismology station recorded higher RMSE compared to Kota Kinabalu station, which is $100 \mathrm{~km}$ away from the earthquake event. This is an interesting observation, as it could indicate that sandstone foundation with higher elevation is more sensitive to detecting an earthquake event.

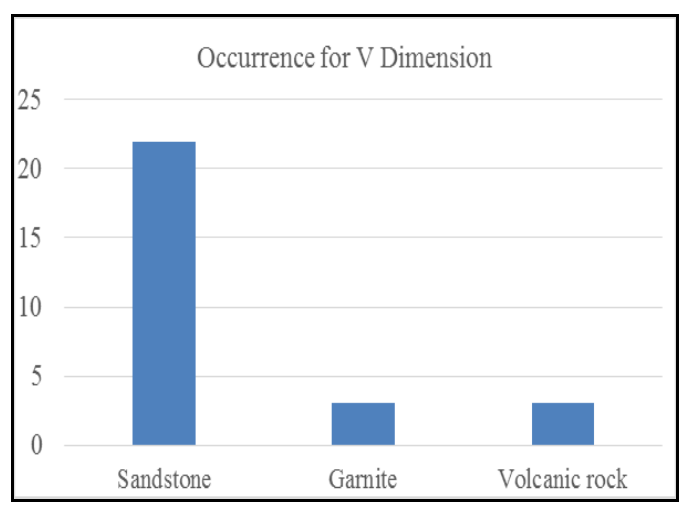

Fig. 11. Occurrence of earthquake events at lowest RMSE value for V dimension.

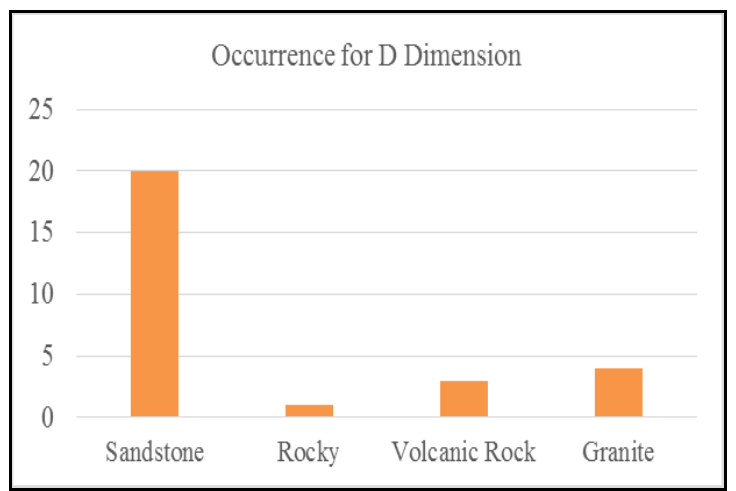

Fig. 12. Occurrence of earthquake events at lowest RMSE value for D dimension.

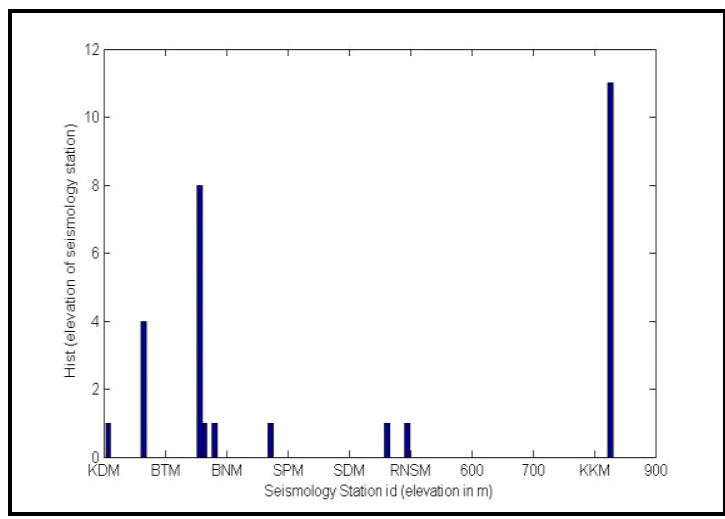

Fig. 13. Histogram of felt earthquake events in Sabah with respect to seismology stations (and respective elevation in $\mathrm{m}$ ).

TABLE IV: SEISMOLOGY STATIONS AND FOUNDATIONS

\begin{tabular}{|c|c|c|}
\hline $\begin{array}{l}\text { Seismology Station } \\
\text { Id }\end{array}$ & Seismology Station & Foundation \\
\hline KKM & Kota Kinabalu & Sandstone \\
\hline RSNM & Ranau & Rocky \\
\hline BTM & Bintulu & Sandstone \\
\hline KDM & Kudat & Granite \\
\hline TSM & Tawau & Sandstone \\
\hline SDM & Sandakan & Sandstone \\
\hline SPM & Sapulut & Sandstone \\
\hline $\mathrm{BNM}$ & Bakun & Sandstone \\
\hline TSM & Tawau & Sandstone \\
\hline
\end{tabular}




\section{CONCLUSION}

Early Warning Systems (EWS) are a major element of disaster risk reduction for global and local hazards by taking decisions in the proper time[10]. Objectives of EWS is to be better prepared to face challenges of the risk of long term or sudden disasters by avoiding and reducing damages and loss, saving human lives, health, economic development and cultural heritage. Due to remote location of seismic sensors, satellite systems can offer coverage and reliability of in transmitting the seismic data.

This paper analyses felt earthquake events for 10 years data, from 2004 to 2014 in Sabah. The study shows significant relation between felt earthquake events and seismic parameters such as intensity, distance to epicentre, foundation and elevation of seismic stations. Analysis result observed that, smallest RMSE value for Acceleration (A), Velocity (V) and Distance (D) parameters are highly correlated to smaller value in distance-to-epicentre. Sandstone foundation with higher elevation is more sensitive to detecting an earthquake event and the similar RMSE trend is observed for higher intensity. Future work includes developing system model which contribute to estimate the nature of felt earth quake event and how this can relate to triggering alert for the local people on the impending impact of the felt earthquake event.

\section{APPENDIX}

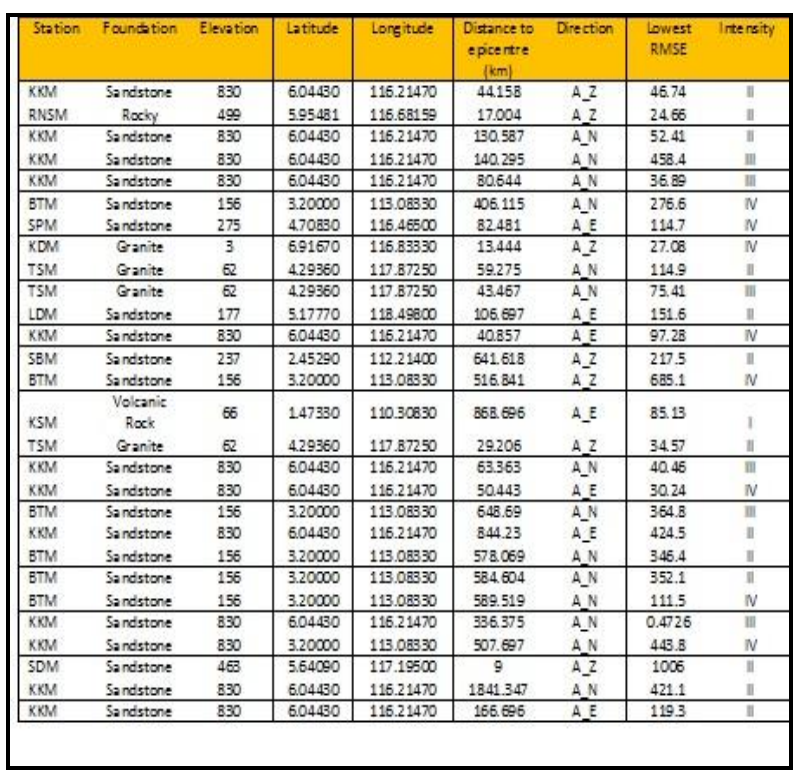

Graph 1. Lowest RMSE for acceleration parameter for 28 felt earthquake events in Sabah, Malaysia.

\begin{tabular}{|c|c|c|c|c|c|c|c|c|}
\hline Station & Foundation & Elevation & Latitude & Longitude & $\begin{array}{l}\text { Distance to } \\
\text { epicentre } \\
(\mathrm{km})\end{array}$ & Direction & $\begin{array}{l}\text { Lowest } \\
\text { RMSE }\end{array}$ & Intensity \\
\hline $\mathrm{KDM}$ & Granite & 6.118 & 6.91670 & 116.83330 & 92.292 & $V_{-} \mathrm{N}$ & 2417 & II \\
\hline SDM & Sandstore & 5.855 & 5.64090 & 117.19500 & 49.975 & $V_{-} E$ & 1016 & II \\
\hline SDM & Sandtotore & 6.773 & 5.64090 & 117.19500 & 126.065 & $\mathrm{~V}_{-} \mathrm{N}$ & 95.1 & II \\
\hline KOM & Sandstore & 6.885 & 6.04430 & 116.21470 & 140.295 & $V_{-} N$ & 28.66 & III \\
\hline SDM & Sandstone & 5.731 & 5.64090 & 117.19500 & 37.129 & $V_{-} E$ & 41.93 & III \\
\hline втM & Sandstore & 5.312 & 3.20000 & 113.08330 & 406.115 & $V_{-} N$ & 66.39 & IV \\
\hline KKM & Sandstore & 5.302 & 6.04430 & 116.21470 & 85.36 & $V_{-} N$ & 85.89 & IV \\
\hline KKM & Sandstore & 6.803 & 6.04430 & 116.21470 & 105.798 & $v_{-} z$ & 49.1 & IV \\
\hline $\mathrm{KKM}$ & Sandstone & 4.559 & 6.04430 & 115.21470 & 287.209 & $V_{-} E$ & 114.9 & II \\
\hline LDM & Sandstore & 4.645 & 5.17770 & 118.49600 & 77.732 & $\mathrm{~V}_{-} \mathrm{N}$ & 184.5 & III \\
\hline KKM & Sandstore & 4.868 & 6.04430 & 116.21470 & 377.067 & $V_{-} N$ & 153 & II \\
\hline BNM & Sandstore & 5.99 & 27760 & 114.03500 & 455.401 & $v_{-} z$ & 59.89 & IV \\
\hline LDM & Sandstore & 6.12 & 5.17770 & 118.49600 & 226.891 & $v_{-} z$ & 149.8 & II \\
\hline TSM & Granite & 6.07 & 4.29360 & 117.87250 & 233.456 & $V_{-} E$ & 153.2 & IV \\
\hline $\mathrm{KKM}$ & Sandstore & 4.113 & 6.04430 & 116.21470 & 268.459 & $V_{-} E$ & 20.66 & 1 \\
\hline SPM & Sandstore & 4.353 & 4.70130 & 116.46500 & 188.693 & $\mathrm{~V}_{-} \mathrm{N}$ & 27.84 & II \\
\hline LDM & Sendstore & 5.864 & 5.17770 & 118.49600 & 207.215 & $V_{-} N$ & 52.3 & III \\
\hline KKM & Sandatone & 6.084 & 6.04430 & 116.21470 & 50.443 & $V_{-} E$ & 26.09 & IV \\
\hline SDM & Sandstore & 5.4 & 5.64090 & 117.19500 & 146.945 & $V_{-} E$ & 39.91 & III \\
\hline KSM & $\begin{array}{c}\text { Volcanic } \\
\text { Rock }\end{array}$ & 1.41 & 1.47330 & 110.30830 & 1326.758 & $V_{-} E$ & 396.3 & II \\
\hline BTM & Sanditore & 4.6 & 3.20000 & 113.08330 & 578.069 & $V_{-} E$ & 22.54 & II \\
\hline KKM & Sandatore & 4.64 & 6.04430 & 116.21470 & 265.203 & $V_{-} E$ & 75.59 & II \\
\hline втМ & Sandstore & 4.73 & 3. 20000 & 113.08330 & 589.519 & $V_{-} E$ & 25.69 & IV \\
\hline KSM & $\begin{array}{c}\text { Volcanic } \\
\text { Rock }\end{array}$ & 4.86 & 1.47330 & 110.30830 & 1087.099 & $v_{-} 2$ & 19.92 & III \\
\hline BTM & Sandstore & 6 & 3.20000 & 113.06330 & 507.697 & $V_{-} E$ & 24.45 & IV \\
\hline TSM & Granite & 4.8 & 4.29360 & 117.87250 & 67.017 & $\mathrm{~V}_{-} \mathrm{N}$ & 93.4 & II \\
\hline KSM & $\begin{array}{c}\text { Volcanic } \\
\text { Rock }\end{array}$ & -5.5 & 147330 & 110.30830 & 2123.253 & $\mathrm{~V}_{-} \mathrm{N}$ & 493.6 & II \\
\hline BTM & Sandstore & 6.3 & 3.20000 & 113.06330 & 617.024 & V_E & 34.3 & II \\
\hline
\end{tabular}

Graph 2. Lowest RMSE for acceleration parameter for 28 felt earthquake events in Sabah, Malaysia. 


\begin{tabular}{|c|c|c|c|c|c|c|c|c|}
\hline Station & Foundstion & Elevation & Latitude & Longitude & $\begin{array}{c}\text { Distance to } \\
\text { epicentre } \\
\{\mathrm{km} \mid\end{array}$ & Direction & $\begin{array}{l}\text { Lovest } \\
\text { RMSE }\end{array}$ & Intensity \\
\hline RNM & Rocky & 499 & 5.95461 & 116.66159 & 19.939 & D_Z & 172.5 & II \\
\hline KKM & Sandstone & 830 & 6.04430 & 116.21470 & 67.879 & D.Z & 35.23 & II \\
\hline KDM & Granite & 3 & 6.91670 & 116.83330 & 37.553 & $\overrightarrow{D_{-} E}$ & 67.56 & II \\
\hline $\mathrm{KKM}$ & Sandstone & 830 & 6.04430 & 116.21470 & 140.295 & D. N & 35.36 & III \\
\hline SDM & Sandstone & 463 & 5.64090 & 117.19500 & 37.129 & D.N & 56.16 & III \\
\hline BTM & Sandstone & 156 & 3.20000 & 113.08330 & 406.115 & D_z & 19.81 & $\mathrm{TN}$ \\
\hline KKM & Sandstone & 830 & 6.04430 & 116.21470 & 85.36 & $D^{-} Z$ & 69.02 & N \\
\hline KDM & Granite & 3 & 6.91670 & 116.83330 & 13.444 & $D_{-} N$ & 40.85 & N \\
\hline $\mathrm{KKM}$ & Sandstone & 830 & 6.04430 & 116.21470 & 287.209 & D.E & 133.1 & II \\
\hline KKM & Sandstone & 830 & 6.04430 & 116.21470 & 255.47 & $\vec{D} N$ & 573.5 & IIII \\
\hline $\mathrm{KKM}$ & Sandstone & 830 & 6.04430 & 116.21470 & 377.057 & D.N & 122.4 & II \\
\hline BNM & Sandstone & 166 & & & 455.401 & D Z & $68.0 B$ & $\mathbb{N}$ \\
\hline KKM & Sandstone & 830 & 6.04430 & 116.21470 & 52.148 & $D_{-} Z$ & 227.1 & II \\
\hline BTM & Sandstone & 156 & 3.20000 & $113.0 \mathrm{~B} 330$ & 516.841 & $\overline{D E}$ & 99.91 & N \\
\hline KSM & Volcanic Rodk & 66 & 1.47330 & 110.30830 & 868.696 & $\overrightarrow{D_{-} E}$ & 6.004 & $T$ \\
\hline TSM & Granite & 62 & 4.29360 & 117.87250 & 29.206 & D.E & 50.13 & II \\
\hline SPM & Sandstone & 275 & 4.70830 & 115.46500 & 132.581 & $D_{-} Z$ & 113.4 & IIII \\
\hline KKM & Sandstone & 830 & 6.04430 & 116.21470 & 50.443 & D.N & 57.89 & in \\
\hline SDM & Sandstone & 468 & 5.64090 & 117.19500 & 146.945 & $\overrightarrow{D_{-} N}$ & 84.91 & IIII \\
\hline BTM & Sandstone & 156 & 3.20000 & 113.08330 & 1036.925 & $D_{-} E$ & 40.47 & II \\
\hline SBM & Sandstone & 237 & 2.45290 & 112.21400 & 695.696 & DEE & 51.88 & II \\
\hline BTM & Sandstone & 156 & 3.20000 & 113.08330 & 584.604 & $\overrightarrow{D_{-} E}$ & 71.24 & II \\
\hline KKM & Sandstone & 830 & 6.04430 & 116.21470 & 261.253 & D.Z & 107.3 & N \\
\hline KSM & Volcanic Rodk & 66 & 1.47330 & 110.30830 & 1037.099 & $D_{-} E$ & 21.57 & IIII \\
\hline $\mathrm{KKM}$ & Sandstone & 830 & 6.04430 & 116.21470 & 53.908 & D. N & 50.19 & N \\
\hline KKM & Sandstone & 830 & 6.04430 & 116.21470 & 259.772 & $D_{-} E$ & 170.2 & II \\
\hline KSM & Volcanic Rodk & 66 & 1.47330 & 110.30830 & 2123.253 & D. N & 462.8 & II \\
\hline TSM & Granite & $E 2$ & 4.29860 & 117.87250 & 223.968 & $D 2$ & 252.5 & II \\
\hline
\end{tabular}

Graph 3. Lowest RMSE for displacement parameter for 28 felt earthquake events in Sabah, Malaysia.

\section{ACKNOWLEDGMENT}

The authors would like to acknowledge research fund from Universiti Putra Malaysia (UPM) entitled ECOSAN: Emergency Communications over Satellite-Assisted Network (Project code: GP-IPB/2013/9413101). ANGKASA's intern, Norhazimah Sanuri - are acknowledged for contributions in seismic data analysis during her industrial training attachment in June-August 2015.

\section{REFERENCES}

[1] Study on the Seismic and Tsunami Hazards and Risks in Malaysia, 2008.

[2] Assessment of the Seismic Threats to Malaysia from Major.

[3] Earthquakes in the Southeast Asian Region, 2008.

[4] Assessment of the Seismic Threats to Malaysia from Major Earthquakes in the Southeast Asian Region, 2008

[5] Ninth Malaysian Plan, Projek Geobencana Negari Sabah, Geological Terrain Mapping of Ranau Area, Sabah, JMG, SBH(GBN), 2010

[6] R. M. Allen, "The status of earthquake early warning around the world: An introductory overview," Seismological Research Letters, vol. 5, no. 5, Sept./Oct. 2009.

[7] Chinese Journal of Geophysics vol. 55, no. 2, 2012, pp. 150-165.

[8] Study on the Seismic and Tsunami Hazards and Risks in Malaysia, 2008.

[9] R. G. D. Steel and J. H. Torrie, Principles and Procedures of Statistics with Special Reference to the Biological Sciences, McGraw Hill, 1960, p. 288.

[10] Y. Nakamura, J. Saita, and T. Sato, "On an earthquake early warning sytem (EEW) and it applications," Soil Dynamic and Earthquake Engineering, vol. 31, 2011.

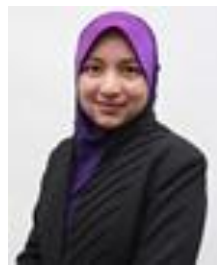

Aduwati Sali is currently an associate professor at the Department of Computer and Communication Systems, Faculty of Engineering, Universiti Putra Malaysia (UPM) since Dec. 2013. She obtained her $\mathrm{PhD}$ in mobile and satellite communications form University of Surrey, UK, in July 2009, her MSc in communications and network engineering from UPM, Malaysia, in April 2002 and her BEng in electrical electronics engineering (communications) from University of Edinburgh, UK, in 1999.

She is the principle investigator and collaborator for projects under the local and international funding bodies; namely Malaysian Ministry of Science, Technology and Innovation (MOSTI), Malaysian Ministry of
Education (MoE), Research University Grant Scheme (RUGS) (now known as Putra Initiative Grant) UPM, The Academy of Sciences for the Developing World (TWAS-COMSTECH) Joint Grants, and EU Horizon2020 Research and Innovation Staff Exchange (H2020-RISE). She gave consultations to Malaysian Ministry of Information and Multimedia, Malaysian Ministry of Education, National Space Agency, ATSB Bhd and Petronas Bhd. on projects related to mobile and satellite communications.

Her research interests are radio resource management, MAC layer protocols, satellite communications, wireless sensor networks, satellite-assisted emergency communications and 3D video transmission over wireless networks. In 2014, the fateful event of missing MH370 has requested her to be in printed and broadcasting media, specifically Astro Awani, RTM, TV Al-Hijrah, BERNAMA, Harian Metro and Metro Ahad, regarding analysis on satellite communication in tracking the aircraft.

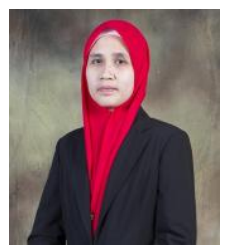

Dasimah Zainal currently serve as a research officer in space industry development division at National Space Agency, Malaysia (ANGKASA). She obtained her MSc in S\&T policy \& management from University Of Malaya, Malaysia in 2010 and the bachelor of electrical engineering from Tun Husse in Onn University, Malaysia in 2005

Given the task of exploiting the satellite technology in developing potential application for the public sector has lead her research interest in the area of satellite communication, radiocommunication, spectrum and frequency management and Internet of Things (IOT).

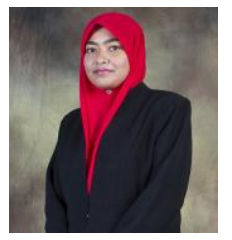

Noor Hidayah Tauhid Ahmad is a research officer at National Space Agency, Malaysia (ANGKASA) under space system development and operation division. She was involved in satellite communication development program, satellite application research activities since 2009 , and operational of acoustic chamber for satellite facility testing since 2012. She graduated from University of Technology Malaysia in 2005 and joined the National Space Agency in 2007.

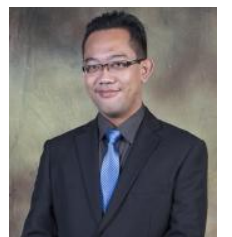

Mohd Farid Omar is a research officer at National Space Agency, Malaysia (ANGKASA). He joined ANGKASA as a researcher in 2011 in space application and technology development divison. Prior to joining ANGKASA, he worked as R\&D engineer for four years at Panasonic and JVC Manufacturing Company. He completed his degree in 2008 at University Technology of Malaysia (UTM) in electrical and computer engineering field. He led a collaborative research programs grant by MOSTI for smart city application and contributed to the areas of satellite communications, radio amateur, and IoT application for smart city. He was IEEE YP ExComm for industry relation for 2015 and 2016. 